\title{
INTERTEXTOS: RELAÇÕES COM O MUNDO NA POESIA DE $O$ HOMEM INACABADO, DE DONIZETE GALVÃO
}

\author{
Audrey Castañón de MATTOS ${ }^{55}$
}

GALVÃO, D. O homem inacabado. São Paulo: Portal, 2010. 72 p.

O homem inacabado, mais recente trabalho do poeta mineiro Donizete Galvão, publicado em 2010, caracteriza-se por manter um intenso - e profícuo - diálogo com o mundo, levado a cabo por meio do recurso da intertextualidade, que estabelece uma série de relações, tanto internas, entre os poemas do próprio volume, quanto com a obra pregressa do autor e com a de outros artistas - poetas, romancistas, pintores.

A quebra da linearidade da leitura - propiciada pelas ligações intertextuais desvendadas pelo leitor -, associada aos temas cantados pelos cinquenta poemas que constituem o volume, recriam no universo poético o mundo que produz o homem inacabado a que o título do livro alude e que o poeta tenta captar.

Esse homem, cujo reflexo o leitor cuidadoso pode vislumbrar em meio ao caos imagético produzido pelos poemas do livro, é o homem contemporâneo, principalmente o que vive no meio urbano, e que se angustia diante da necessidade de lidar com as complexas relações impostas por seu mundo e por seu tempo: relações que, de uma forma ou de outra, exigem dele, sempre, uma tomada de posição, uma escolha. Não poder, nunca, possuir ou alcançar o que quer que seja sem que algo tenha de ser preterido; daí esse homem ser incompleto, inacabado: há sempre uma parte dele que ficou para trás e há sempre uma parte dele a ser construída, porque cada escolha impõe um recriar-se a si próprio.

O projeto temático do livro - bem como sua estrutura multilinear - pode ser resumido em dois símbolos: a epígrafe de Aníbal Machado, retirada do livro Cadernos de João, e as ilustrações do artista plástico Rogério Barbosa.

Dispostas nas páginas iniciais (há também uma ilustração de Barbosa no final do livro) tanto a epígrafe quanto as imagens antecipam a viagem ao interior do homem e a

\footnotetext{
55 Mestranda. Programa de Pós-Graduação em Estudos Literários, Faculdade de Ciências e Letras, Universidade Estadual Paulista, UNESP, campus de Araraquara, CEP 14800-901, Araraquara, SP, Brasil - audreymattos@hotmail.com
} 
forma multifacetada como esse homem se liga ao mundo, por meio da religião, do trabalho, das artes e das relações interpessoais.

Semelhantes a radiografias, as imagens de Rogério Barbosa sugerem a visão do avesso do homem, da sua estrutura confusa e desconcertante, pois impossível de ser traduzida ao primeiro olhar.

A epígrafe, por sua vez, antecipa os pontos norteadores da poesia de $O$ homem inacabado: o diálogo intertextual intenso, a quebra da linearidade da leitura (característica marcante dos Cadernos de João, de Aníbal Machado), a atualização de elementos da tradição clássica, pois o trecho em epígrafe, além de remeter para a própria temática do livro - a da incompletude do homem - resgata o mito platônico da divisão do homem em duas metades que se buscariam por toda a vida: "A metade que parecia dele ficou a esperar a outra, que se forjava na cidade dividida. Não conseguia juntá-las.” (MACHADO apud GALVÃO, 2010, p. 3).

O poema "Anedota japonesa" (p. 12) sintetiza com eloquência as características da poesia de $O$ homem inacabado: seus jogos intertextuais, a tendência expressionista ao exagero das imagens para tentar esboçar o estar no mundo do homem contemporâneo, a erudição desvelada a cada remissão dos poemas a obras de outros artistas. Principalmente, "Anedota japonesa" sintetiza o mundo cantado nas páginas deste livro: antagônico, espaço de lutas que, obrigando o homem a constantes escolhas e perdas, faz dele um ser estilhaçado e com um sentido de incompletude latente.

O poema, transcrito integralmente a seguir, constrói-se em torno de seis ícones que apontam tanto para características desse mundo a que se refere como para as marcas que, conforme mencionamos, caracterizam este trabalho de Donizete Galvão:

\footnotetext{
"Anedota japonesa"

Peixes mecânicos nadam, raros, no aquário em Osaka.

Seu terno de vidro quebrou no armário de espanto.

Um corvo com bico de aço volta a furar seu cérebro.

As vísceras de Mishima pulam debaixo da cama.

Nenhum cão na imensa Tóquio ganirá por sua solidão.
} 
(GALVÃO, 2010, p.12).

O primeiro ícone, o Japão, referenciado no título do poema, é a representação metonímica do mundo atual, com as contradições impostas pela convivência entre velhas crenças e comportamentos e as novas configurações sociais delineadas, principalmente, pelo avanço tecnológico, que determina cortes profundos na forma como os homens se relacionam entre si e com seu entorno.

O segundo ícone é o Aquário de Osaka (Kaiyukan). Considerado o maior do mundo, Kaiyukan é entendido pelo poeta como símbolo do mecanicismo e artificialismo com que o homem tenta equiparar-se à natureza. Seus esforços, entretanto, são baldados: no maior aquário do mundo os peixes são raridade.

No segundo dístico do poema os termos "terno de vidro" - referência explícita ao poema "José", de Drummond - e "espanto", que, em se tratando de poesia remete imediatamente ao poeta Ferreira Gullar, indicam que o terceiro ícone do poema é a própria Poesia e sua forma de recriar o mundo. O terno de vidro, que em "José" já denotava a fragilidade do homem, agora quebrado denuncia seu esfacelamento, seu sentimento de fragmentação, para espanto do poeta, desta vez, diante não da beleza do mundo, mas do seu aspecto de "engrenagem produtora de ruínas" (GALVÃO, 2010, p.7).

Daí o corvo - ave que para algumas culturas é símbolo de maus presságios - ser outro ícone do poema. Será, talvez, o mesmo corvo de Poe, que atravessou os séculos e pousou na contemporaneidade, agora com bico de aço, tanto mais contundente quanto a era que visita. Seu incansável never more - fonte de inquietação e desespero - agora ressignificado, aponta para o caminho sem volta para o qual o homem marcha, tal qual o José drummondiano, que não sabe aonde esse caminho vai dar, mas não pode impedirse de continuar nele.

A imagem suscitada pelas "vísceras de Mishima" - quinto ícone do poema pulando sob a cama, é o quadro do desassossego que caracteriza o homem moderno, mesmo em seus momentos de recolhimento e repouso. O suicídio do escritor japonês Yuko Mishima, pelo tradicional ritual do Seppuku, contrapõe um mundo em constante transformação a crenças e valores que, ainda que aparentemente desprovidos de significado na nova ordem social, continuam dividindo opiniões e ditando padrões de comportamento. 
No dístico final, a "imensa Tóquio" simboliza, por antítese, a pequenez do homem. Sua sonoridade e temática, que fazem lembrar os "Versos íntimos" de Augusto dos Anjos - mais uma vez é recuperada, neste poema, a característica da intensa intertextualidade de $O$ homem inacabado -, apontam para o sentimento perene de solidão e de incompreensão que o homem tem diante do mundo que cada vez mais se lhe parece paradoxal.

A temática da antítese é trabalhada também na forma do poema, cujos dísticos, em sua maioria, são metrificados em redondilhas maiores - a escolha da medida velha para falar do mundo atual complementa a mensagem veiculada no poema, assim como os ícones, todos associados de alguma forma ao exagero: o maior aquário do mundo, corvo com bico de aço, vísceras vivas sob a cama, a imensa Tóquio.

Tal é a leitura do mundo que se pode depreender do poema. A anedota japonesa traduz a piada de mau gosto que é, para o homem, o estar em um mundo que constantemente lhe toma algo, o faz sentir-se inacabado.

\section{REFERÊNCIAS}

GALVÃO, D. O homem inacabado. São Paulo: Portal, 2010.

MACHADO, A. M. A arte de viver e outras artes. Cadernos de João, ensaios, crítica dispersa, auto-retratos. Rio de Janeiro: Graphia editorial, 1994. 